Sains Malaysiana 50(4)(2021): 945-952

http://doi.org/10.17576/jsm-2021-5004-06

\title{
Grape Seed Proanthocyanidin Improves Lipopolysaccharide-Induced Myocardial Toxicity in Mice
}

(Proantosianidin Biji Anggur Menambahbaik Ketoksikan Miokardium pada Tikus yang Diaruh Lipopolisakarida)

\author{
Liu Xianchu, Li Sha, Chen Ruyan, Li Yue, Peng Huan \& LiU Ming*
}

\section{ABSTRACT}

Lipopolysaccharide (LPS) is an important pathogenic factor for sepsis which results in cardiovascular diseases and even mortality. Proanthocyanidin, one of the main components in grape seed, has a wide range of biological activities in various diseases. The mouse model was established by intraperitoneal injection with LPS. Grape seed proanthocyanidin (GSP) was administered continuously for 8 days. Our results showed that pre-treatment of GSP dramatically ameliorated the level of creatine kinase (CK) and lactate dehydrogenase (LDH) to defend against LPS-induced myocardial toxicity $(p<0.01)$. Moreover, pre-treatment of GSP significantly mitigated the expression of matrix metallopeptidase 2 $(M M P-2)$ and matrix metallopeptidase $9(M M P-9)$ to inhibit LPS-induced myocardial fibrosis $(p<0.01)$. In addition, pre-treatment of GSP significantly increased superoxide dismutase (SOD) and catalase (CAT) activities to improve the level of malondialdehyde (MDA) and hydrogen peroxide $\left(\mathrm{H}_{2} \mathrm{O}_{2}\right)(p<0.01)$. Lastly, pre-treatment of GSP relieved tumor necrosis factor alpha $(T N F-\alpha)$ and interleukin 6 (IL-6) activities to prevent inflammatory responses $(p<0.01)$.

Keywords: Anti-inflammatory; anti-oxidant; grape seed proanthocyanidin; heart; lipopolysaccharide

\section{ABSTRAK}

Lipopolisakarida (LPS) adalah faktor patogen penting untuk sepsis yang mengakibatkan penyakit kardiovaskular dan juga kematian. Proantosianidin iaitu salah satu komponen utama dalam biji anggur mempunyai julat aktiviti biologi yang luas dalam pelbagai penyakit. Model tikus dibangunkan melalui suntikan intraperitoneum menggunakan LPS. Proantosianidin biji anggur (GSP) diberikan secara berterusan selama 8 hari. Hasil kajian kami menunjukkan bahawa pra-rawatan GSP meningkatkan tahap kreatina kinase (CK) dan laktat dehidrogenase (LDH) dengan secara dramatik untuk mempertahankan diri terhadap ketoksikan miokardium yang diaruh oleh LPS $(p<0.01)$. Tambahan pula, pra-rawatan GSP secara signifikan mengurangkan pengekspresan matriks metallopeptida 2 (MMP-2) dan matriks metallopeptida 9 (MMP-9) dengan signifikan untuk menghalang fibrosis miokardium yang diaruh LPS ( $<0.01)$. Di samping itu, prarawatan GSP meningkatkan aktiviti superoksida dismutase (SOD) dan katalase (CAT) dengan signifikan untuk meningkatkan tahap malondialdehida (MDA) dan hidrogen peroksida $\left(\mathrm{H}_{2} \mathrm{O}_{2}\right)(p<0.01)$. Akhir sekali, pra-rawatan GSP menekan aktiviti faktor nekrosis tumor alpha (TNF- $\alpha$ ) dan interleukin 6 (IL-6) untuk mencegah tindak balas keradangan (p $<0.01)$.

Kata kunci: Anti-oksidan; anti-radang; jantung; lipopolisakarida; proantosianidin biji anggur

\section{INTRODUCTION}

Sepsis is a complex and severe disease, which could cause multiple organ failure such as liver and heart injury (Polat et al. 2017). LPS which is derived from Gram-negative bacteria plays a high-risk factor in sepsis. Nowadays, heart diseases in sepsis are becoming major factors of death in hospitalized patients (Chagnon et al. 2005; Court et al. 2002). In the animal models, LPS increased fibrosis relevant genes expression in heart (Lew et al. 2013). Moreover, a number of studies have shown that the main cause of myocardial toxicity in sepsis may be due to excessive oxidative stress ( $\mathrm{Li}$ et al. 2016). Inflammatory response is also one of the leading and growing causes of LPS-induced heart impairment (Zhao et al. 2015). 
Proanthocyanidin is abundantly found in grape seed and has beneficial health effects with the antioxidant and anti-inflammatory functions. GSP protects liver and brain against TPA-induced lipid peroxidation and DNA fragmentation (Bagchi et al. 1998). GSP decreased TNF- $\alpha$ and IL-6 levels to ameliorate inflammation in AFB1induced mouse (Long et al. 2016). In doxorubicin-induced cardiac injury, GSP mediates its cardioprotective properties through antioxidant and anti-inflammatory activities (Boghdady 2013). In LPS-stimulated macrophages, GSP has potent antioxidant effects by decreasing NO and ROS production and iNOS expression (Houde et al. 2006). However, there is no research on the cardioprotective properties of proanthocyanidin on LPS-induced myocardial toxicity in mouse. We assumed that proanthocyanidin has myocardial protection effects against sepsis owing to its antioxidant and anti-inflammatory properties. Thus, it is necessary to clarify the relationship between proanthocyanidin and sepsis-induced myocardial toxicity, and further demonstrate GSP as a novel curative approach to mitigate sepsis-associated myocardial toxicity.

In this study, mouse model of LPS-induced myocardial toxicity was established to investigate myocardial protection effect of GSP and its underlying mechanisms. In this model, we demonstrated that GSP treatment significantly attenuated cardiac marker enzyme and cardiac fibrosis relevant genes against LPS-induced myocardial toxicity. In addition, the cardioprotective effect of GSP was associated with suppressing excessive oxidative stress and proinflammatory cytokine production in the heart. Our research showed that GSP improved oxidative stresses and inflammatory responses to attenuate LPS-associated myocardial toxicity.

\section{MATERIALS AND METHODS \\ PREPARATION OF ANIMALS}

Sixty male BALB/c mice (8-10 weeks old, $23 \pm 2 \mathrm{~g}$ ) from Hunan SJA Laboratory Animal Co., Ltd. were kept in specific pathogen free (SPF) condition with ad libitum access to standard water and rodent chow. Animal experiments were approved by Animal Care Committee of Hunan Normal University (2017129).

\section{EXPERIMENTAL PROTOCOLS}

The control group was fed with physiological saline $(0.1 \mathrm{~mL})$. Mice were treated with LPS $(10 \mathrm{mg} / \mathrm{kg})$ to establish sepsis-induced myocardial toxicity on the 8th day. The purity of proanthocyanidin was $>95 \%$. Oligomeric proanthocyanidins is the major constituents of proanthocyanidin, which accounted for $60 \%$. GSP $(100 \mathrm{mg} /(\mathrm{kg} \cdot \mathrm{d}))$ were given intragastrically for 8 days (Figure 1).

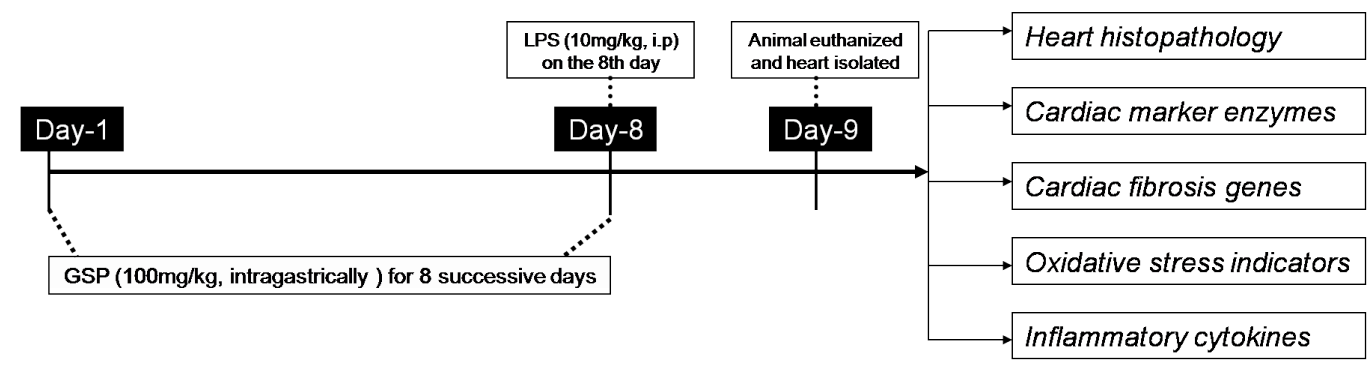

FIGURE 1. The experiment scheme and research indicators in this study

\section{HEART HISTOPATHOLOGICAL EVALUATIONS}

Heart was separated and fixed on paraformaldehyde (4\%). Cardiac tissue was embedded into paraffin and cut into slices. Then, sections were stained with hematoxylin and eosin to assess cardiac pathology, which was viewed with light microscope (200 X).

\section{DETECTIONS OF CARDIAC MARKER ENZYMES}

Mice were killed and blood samples were harvested from the eyeball on the 9th day. The cardiac marker enzymes (Catalog number: A020-1 for LDH, A032 for $\mathrm{CK}$ ) in serum were determined to evaluate heart injury according to the instructions. 


\section{OXIDATIVE STRESS MEASUREMENTS}

Heart tissues were obtained, sonicated and homogenised. Then, the ground mixture of heart tissues was centrifuged to separate supernatant, which was collected for oxidative stress analysis. SOD (Catalog number: A001-1) and CAT (Catalog number: A007-1) were determined to evaluate antioxidative action. MDA (Catalog number: A003-1) and hydrogen peroxide (Catalog number: A064) were tested to detect oxidative stress.

\section{ELISA ANALYSES}

Fibrosis indicators (Catalog number: EK0460 for MMP-2, EK0466 for MMP-9) and inflammatory cytokines
(Catalog number: EK0527 for TNF- $\alpha$, EK0411 for IL6) were determined in the heart tissues according to manufacturer's instructions.

\section{RNA EXTRACTION AND RT-PCR ANALYSIS}

Total RNA was extracted from heart tissues of mice by trizol method and reversed into cDNA for evaluating gene expression. Then, RT-PCR was used to test mRNA expression of MMP-2, MMP-9, TNF- $\alpha$ and IL-6. Primer sequences were synthesized by TSINGKE Biological Technology Co. Ltd. and Biosune Biological Technology Co. Ltd. (Table 1).

TABLE 1. Primer sequences of target genes

\begin{tabular}{ll}
\hline Gene & Primer sequences $\left(5^{\prime}->3^{\prime}\right)$ \\
\hline GAPDH & Forward: AACTTTGGCATTGTGGAAGG \\
& Reverse: ACACATTGGGGGTAGGAACA \\
MMP-2 & Forward: GTCGCCCCTAAAACAGACAA \\
& Reverse: GGTCTCGATGGTGTTCTGGT \\
MMP-9 & Forward: CGTCGTGATCCCCACTTACT \\
& Reverse: AACACACAGGGTTTGCCTTC \\
TNF-a & Forward: ACCCTCACACTCACAAACCA \\
& Reverse: GGCAGAGAGGAGGTTGACTT \\
IL-6 & Forward: CCACCAAGAACGATAGTCAA \\
& Reverse: TTTCCACGATTTCCCAGA \\
\hline
\end{tabular}

\section{STATISTICS}

All results were shown as mean \pm SD. The data were statistically analysed with SPSS 16.0 software. Statistical significance was performed with one-way ANOVA. $p<0.05$ was deemed statistically significant.

\section{RESULTS}

EFFECT OF GSP ON HEART INJURY IN LPS-TREATED MICE In LPS group, mice suffered severe heart damage, as represented by inflammatory cell infiltration, while LPS-induced morphological change of myocardium was improved in GSP group (Figure 2(A)-2(C)). To further estimate the properties of GSP on LPS-induced myocardial toxicity, cardiac marker enzymes activity was measured. The activity of CK and LDH in serum was significantly increased in LPS group. On the contrary, GSP group had significantly lower CK and LDH than those in LPS group (Figure 2(D) and 2(F)). 
A

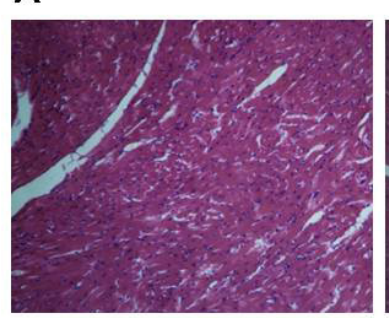

CON

D

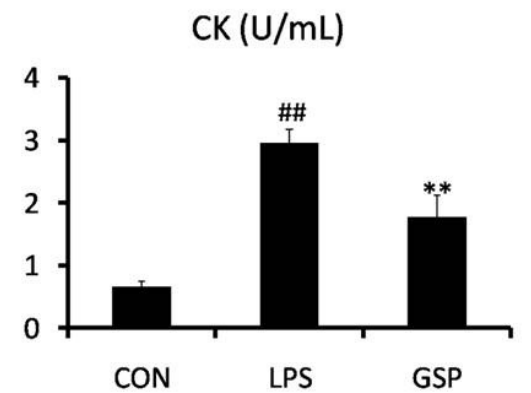

B

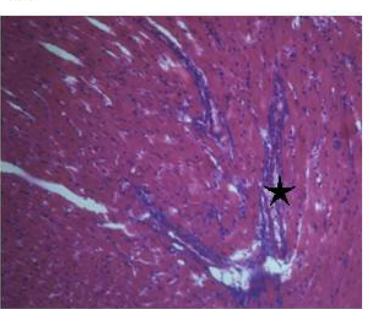

LPS
C

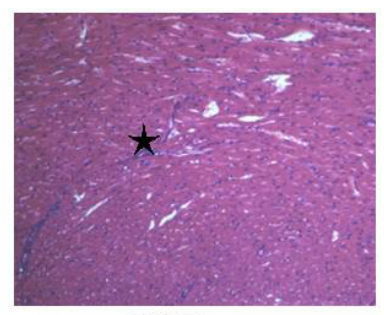

GSP

$\mathbf{F}$

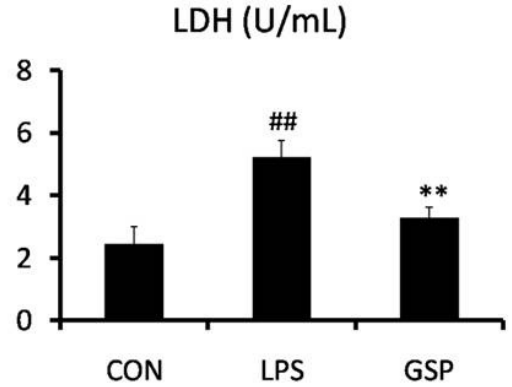

FIGURE 2. Effect of GSP on heart injury in LPS-treated mice. A-C: morphological change of myocardium was analysed according to histopathological morphology via HE staining (200X magnification). D: representative of CK activity in serum. F: representative of LDH activity in serum. é: inflammatory cell infiltration. CON: control. LPS: lipopolysaccharide. GSP: grape seed proanthocyanidin+ lipopolysaccharide. \#\#p $<0.01$ vs CON group. ${ }^{* *} \mathrm{p}<0.01$ vs LPS group

\section{EFFECT OF GSP ON FIBROSIS}

To further study the properties of GSP on LPS-induced myocardial toxicity, fibrosis related genes were investigated in this study. The mRNA expression of MMP-2 and MMP-9 was increased in LPS group, while the

\section{A}

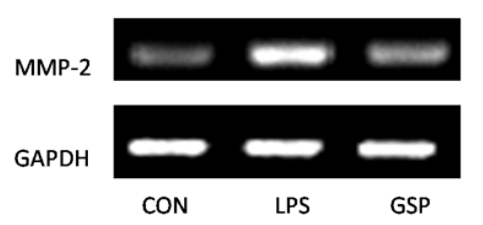

C

\section{MMP-2(ng/mg protein)}

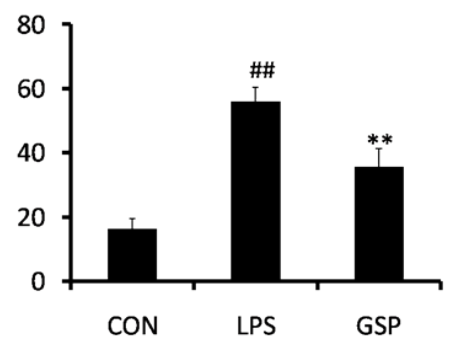

mRNA expression of MMP-2 and MMP-9 was decreased in GSP group (Figure 3(A) and 3(B)). Similarly, protein expression of MMP-2 and MMP-9 was remarkably decreased in heart from GSP group compared with LPS group (Figure 3(C) and 3(D)).
B

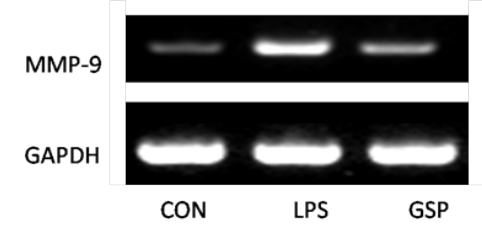

D

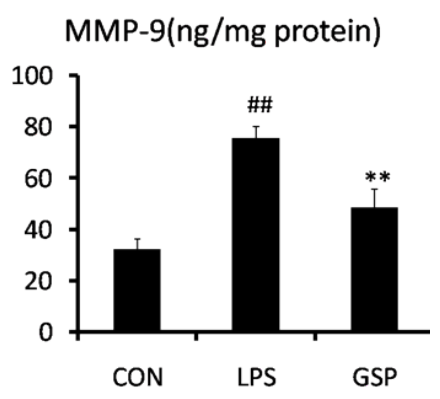

FIGURE 3. Effect of GSP on cardiac fibrosis. A, B: mRNA expression of MMP-2 and MMP-9 were analyzed by RT-PCR. C, D: protein expression of MMP-2 and MMP-9 were determined by ELISA. GAPDH was used as internal reference to normalize the samples. CON: control. LPS: lipopolysaccharide. GSP: grape seed proanthocyanidin+ lipopolysaccharide. $\# \#$ p $<0.01$ vs CON group. ${ }^{* *}$ p $<0.01$ vs LPS group 


\section{EFFECT OF GSP ON OXIDATIVE STRESS}

Antioxidant enzymes and oxidative indicators were investigated to evaluate the oxidative stress on LPSinduced myocardial toxicity. The activity of SOD and CAT was markedly decreased in LPS group. Nevertheless, administration of GSP statistically increased SOD and
CAT activities in heart compared with the control group (Figure 4(A) and 4(B)). As expected, MDA and $\mathrm{H}_{2} \mathrm{O}_{2}$ levels were markedly increased in LPS group. In contrast, treatment with GSP statistically decreased MDA and $\mathrm{H}_{2} \mathrm{O}_{2}$ in heart (Figure 5(A) and 5(B)).

\section{A}

$\mathrm{SOD}(\mathrm{U} / \mathrm{mg}$ protein)

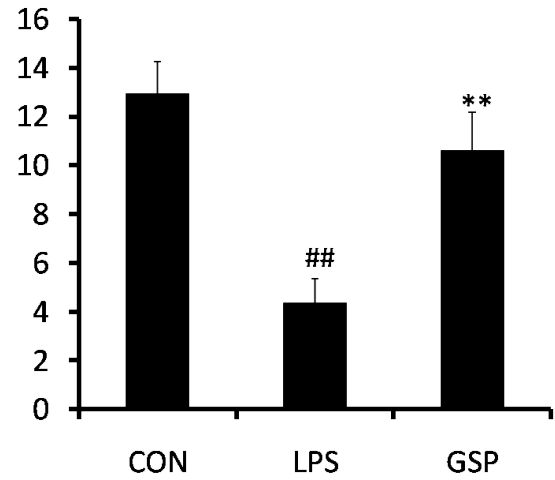

B

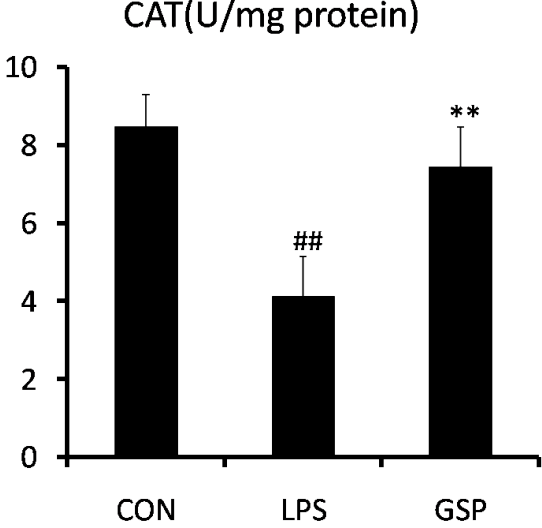

FIGURE 4. Effect of GSP on antioxidant enzymes. A: detection of SOD activity in heart. B: detection of CAT activity in heart. CON: control. LPS: lipopolysaccharide. GSP: grape seed proanthocyanidin+ lipopolysaccharide. \#\#p $<0.01$ vs CON group. ${ }^{* *}$ p $<0.01$ vs LPS group

A

\section{MDA(nmol/mg protein)}

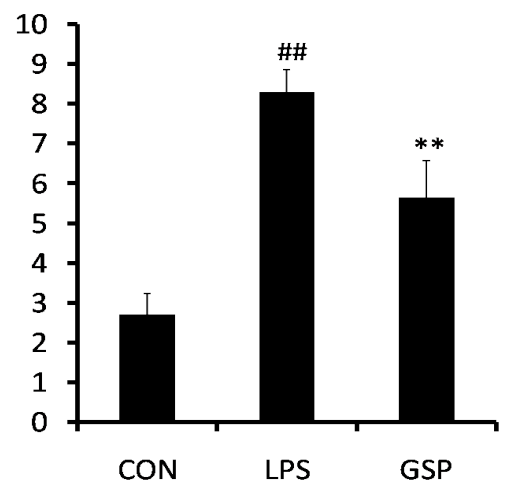

B

$\mathrm{H}_{2} \mathrm{O}_{2}(\mathrm{mmol} / \mathrm{g}$ protein)

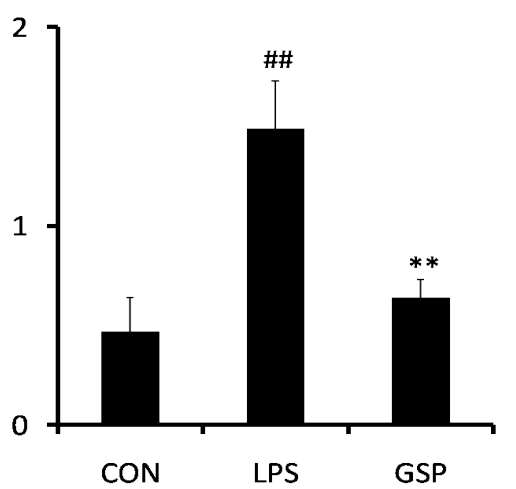

FIGURE 5. Effect of GSP on oxidative indicators. A: measurement of MDA level. B:

measurement of $\mathrm{H}_{2} \mathrm{O}_{2}$ level. CON: control. LPS: lipopolysaccharide. GSP: grape seed proanthocyanidin+ lipopolysaccharide. \#\#p $<0.01$ vs CON group. ${ }^{*} * \mathrm{p}<0.01$ vs LPS group 


\section{EFFECT OF GSP ON CYTOKINES}

TNF- $\alpha$ and IL- 6 were detected to investigate the effect of GSP on inflammatory response. The mRNA expression of TNF- $\alpha$ and IL- 6 was enhanced in LPS group, while the
mRNA expression of TNF- $\alpha$ and IL- 6 was reduced in GSP group (Figure 6(A) and 6(B)). Similarly, treatment with GSP significantly reduced protein expression of TNF- $\alpha$ and IL-6 (Figure 6(C) and 6(D)).

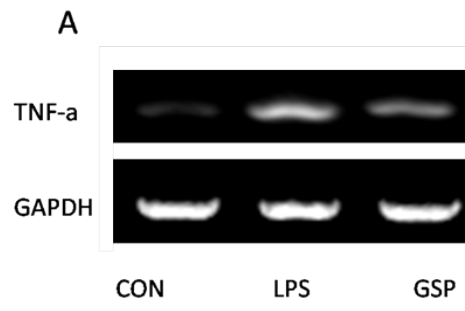

C

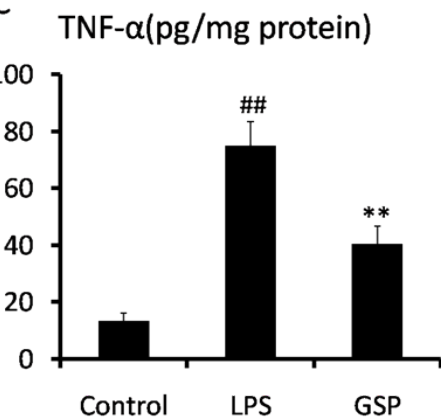

B

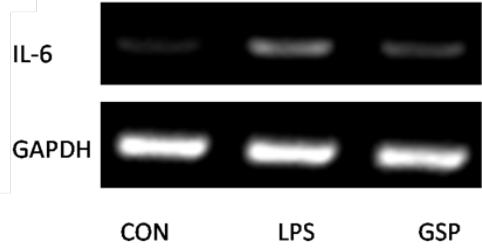

D

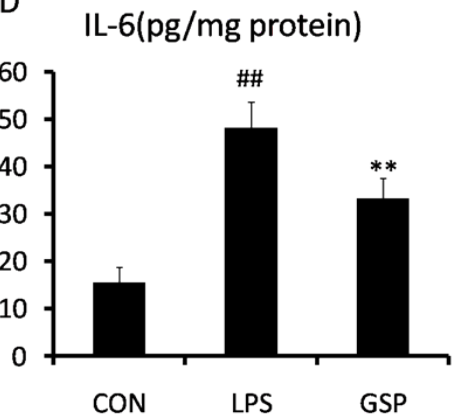

FIGURE 6. Effect of GSP on cytokines. A, B: mRNA expression of TNF- $\alpha$ and IL-6 were analysed by RT-PCR. C, D: protein expression of TNF- $\alpha$ and IL- 6 were determined

by ELISA. GAPDH was used as internal reference to normalize the samples. LPS: Lipopolysaccharide, GSP: grape seed proanthocyanidin+ Lipopolysaccharide. \#\#p $<0.01$ vs CON group. $* * p<0.01$ vs LPS group

\section{DISCUSSION}

Proanthocyanidin is a polyphenol which has been reported to possess multiple curative effects in many organs such as heart, liver and brain (Mansouri et al. 2011). In doxorubicin-induced cardiotoxicity, GSP ameliorated CK level in serum to protect the heart (Demirkaya et al. 2009). Proanthocyanidin was also reported to show potential effects on thioacetamide-induced hepatic fibrosis ( $\mathrm{Li}$ et al. 2012). In addition, GSP has various biological properties including anti-oxidant and antiinflammation. In doxorubicin-intoxicated rats, GSP showed a prohibitive action on TNF- $\alpha$ expression (Boghdady 2013). In LPS-stimulated macrophages, GSP has anti-oxidant activity by strongly restraining ROS production (Houde et al. 2006). However, the underlying protective mechanism of GSP in LPS-induced sepsis is not clear yet.
The major results from this study were as follows. Firstly, GSP improved cardiac lesions and relieved CK and LDH levels in serum. Further studies showed that GSP was observed to alleviate MMP-2 and MMP-9 expression to inhibit fibrosis in the LPS-induced myocardial toxicity. Furthermore, GSP significantly regulated antioxidant enzymes and oxidative indicators to mitigate oxidative stress in heart. Lastly, we also observed GSP is highly effective in improving TNF- $\alpha$ and IL- 6 levels against inflammatory response.

Sepsis is harmful to multiple organs in intensive care unit (Minasyan 2017; Suzuki et al. 2017). In animal experiments, it has also been demonstrated that sepsis has a crucial manifestation in toxicity by reducing myocardial function and triggering cardiac fibrosis (Lew et al. 2014). As LPS was involved in the development of 
sepsis, the model of sepsis-associated myocardial toxicity was established using LPS in mice. Cardiac marker enzymes are known to be important indicators for heart injury. According to this model, cardiac enzymes are determined to evaluate myocardial toxicity and high activity of CK and LDH to indicate that heart injury has occurred or was occurring. In addition, administration with GSP could decrease serum CK and LDH levels in LPS-treated mouse. On the other hand, myocardial toxicity may occur as a result of cardiac fibrosis. In this study, administration with GSP could improve LPS-induced cardiac fibrosis by alleviating MMP-2 and MMP-9 expression. Based on these results, LPS-induced myocardial toxicity was confirmed by enhancing cardiac fibrosis, while GSP has significant effects of alleviating myocardial toxicity after LPS challenge throughout the experiment.

Oxidative stress is involved in a variety of disorders, which occurs as a result of the inhibition of antioxidant enzymes and release of oxidative indicators. The heart is one of the target organs. Antioxidant enzymes such as SOD and CAT play a critical role in scavenging free radicals, and therefore are used as indicators to evaluate the effect of antioxidant defense system (Elias et al. 2008). The present study indicated that SOD and CAT activities were significantly decreased in myocardial ischemia/reperfusion injury, which was reversed by xanthones with anti-oxidation (Wang et al. 2017a). In addition, LPS was reported to accelerate oxidative process by inhibiting antioxidant enzymes. In LPS-induced sepsis, butyrate pretreatment could attenuate heart depression by ameliorating SOD and CAT activity (Wang et al. 2017b). In our study, GSP was observed to enhance SOD and CAT activities in reducing oxidative response during LPS-induced myocardial toxicity.

During the process of LPS-induced sepsis, MDA and $\mathrm{H}_{2} \mathrm{O}_{2}$, as by-products of metabolic, are harmful to heart. The present study indicated that $\alpha$-LA was demonstrated as a free radical scavenger and a potent antioxidant against LPS-induced myocardial toxicity by decreasing the concentration of $\mathrm{H}_{2} \mathrm{O}_{2}$ (Goraca et al. 2009). In addition, resveratrol has shown the down regulation of MDA in protecting cardiac function during LPS-induced sepsis (Bai et al. 2016). In our experimental model, GSP is a potent antioxidant by improving the level of MDA and $\mathrm{H}_{2} \mathrm{O}_{2}$ in LPS-induced myocardial toxicity.

LPS is a vital inducer on inflammatory response. Inflammation plays a primary role in heart diseases, and previous study has shown that elevations of cytokines are relevant to LPS-induced myocardial toxicity. Salidroside pretreatment displayed its cardioprotective effects in rats that had been subjected to LPS via decreasing TNF-a and IL-1 $\beta$ levels in serum (He et al. 2015). Our results showed that GSP decreased TNF- $\alpha$ and IL-6 levels during LPS challenge, which suggested that its cardioprotective effects on sepsis-induced myocardial toxicity was associated with anti-inflammatory effect.

\section{CONCLUSION}

In this study, we proved for the first time that GSP has cardiac protection effects by regulating oxidative stresses and inflammatory responses in sepsis. Hence, GSP is a novel effective agent to improve myocardial toxicity in LPS-induced sepsis.

\section{ACKNOWLEDGEMENTS}

This study was supported in part by a project supported by Scientific Research Fund of Hunan Provincial Education Department (Grant No.18B402), Hunan Provincial Natural Science Foundation of China (Grant No. 2020JJ5391), and Hunan University of Arts and Science Doctor Foundation (Grant No.18BSQD26).

\section{REFERENCES}

Bagchi, D., Garg, A., Krohn, R.L., Bagchi, M., Bagchi, D.J., Balmoori, J. \& Stohs, S.J. 1998. Protective effects of grape seed proanthocyanidins and selected antioxidants against TPA-induced hepatic and brain lipid peroxidation and DNA fragmentation, and peritoneal macrophage activation in mice. General Pharmacology: The Vascular System 30(5): 771-776.

Bai, T., Hu, X., Zheng, Y., Wang, S., Kong, J. \& Cai, L. 2016. Resveratrol protects against lipopolysaccharide-induced cardiac dysfunction by enhancing SERCA2a activity through promoting the phospholamban oligomerization. American Journal of Physiology-Heart and Circulatory Physiology 311(4): H1051-H1062.

Boghdady, N.A.E. 2013. Antioxidant and antiapoptotic effects of proanthocyanidin and ginkgo biloba extract against doxorubicin-induced cardiac injury in rats. Cell Biochemistry \& Function 31(4): 344-351.

Chagnon, F., Metz, C.N., Bucala, R. \& Lesur, O. 2005. Endotoxininduced myocardial dysfunction: Effects of macrophage migration inhibitory factor neutralization. Circulation Research 96(10): 1095-1102.

Court, O., Kumar, A., Parrillo, J.E. \& Kumar, A. 2002. Clinical review: Myocardial depression in sepsis and septic shock Critical Care 6(6): 500-508.

Demirkaya, E., Avci, A., Kesik, V., Karslioglu, Y., Oztas, E., Kismet, E., Gokcay, E., Durak, I. \& Koseoglu, V. 2009. Cardioprotective roles of aged garlic extract, grape seed proanthocyanidin, and hazelnut on doxorubicininduced cardiotoxicity. Canadian Journal of Physiology \& Pharmacology 87(8): 633-640. 
Elias, R.J., Kellerby, S.S. \& Decker, E.A. 2008. Antioxidant activity of proteins and peptides. Critical Reviews in Food Science and Nutrition 48(5): 430-441.

Goraca, A., Piechota, A. \& Huk-Kolega, H. 2009. Effect of alpha-lipoic acid on LPS-induced oxidative stress in the heart. Journal of Physiology and Pharmacology 60(1): 61-68.

He, H., Chang, X., Gao, J., Zhu, L., Miao, M. \& Yan, T. 2015. Salidroside mitigates sepsis-induced myocarditis in rats by regulating IGF-1/PI3K/Akt/GSK-3 $\beta$ signaling. Inflammation 38(6): 2178-2184.

Houde, V., Grenier, D. \& Chandad, F. 2006. Protective effects of grape seed proanthocyanidins against oxidative stress induced by lipopolysaccharides of periodontopathogens. Journal of Periodontology 77(8): 1371-1379.

Lew, W.Y., Bayna, E., Molle, E.D., Contu, R., Condorelli, G. \& Tang, T. 2014. Myocardial fibrosis induced by exposure to subclinical lipopolysaccharide is associated with decreased miR-29c and enhanced NOX2 expression in mice. PLoS ONE 9(9): e107556.

Lew, W.Y., Bayna, E., Molle, E.D., Dalton, N.D., Lai, N.C., Bhargava V., Mendiola, V., Clopton, P. \& Tang, T. 2013. Recurrent exposure to subclinical lipopolysaccharide increases mortality and induces cardiac fibrosis in mice. PLOS ONE 8(4): e61057.

Li, F., Lang, F., Zhang, H., Xu, L., Wang, Y. \& Hao, E. 2016. Role of TFEB mediated autophagy, oxidative stress, inflammation, and cell death in endotoxin induced myocardial toxicity of young and aged mice. Oxidative Medicine \& Cellular Longevity 2016: 5380319.

Li, J., Li, J., Li, S., He, B., Mi, Y., Cao, H., Zhang, C. \& Li, L. 2012. Ameliorative effect of grape seed proanthocyanidin extract on thioacetamide-induced mouse hepatic fibrosis. Toxicology Letters 213(3): 353-360.

Long, M., Zhang, Y., Li, P., Yang, S.H., Zhang, W.K., Han, J.X., Wang, Y. \& He, J.B. 2016. Intervention of grape seed proanthocyanidin extract on the subchronic immune injury in mice induced by aflatoxin B1. International Journal of Molecular Sciences 17(4): 516.

Mansouri, E., Khorsandi, L. \& Abdollahzade, F.A. 2015. Protective role of grape seed proanthocyanidin antioxidant properties on heart of streptozotocin-induced diabetic rats. Veterinary Research Forum 6(2): 119-124.

Minasyan, H. 2017. Sepsis and septic shock: Pathogenesis and treatment perspectives. Journal of Critical Care 40: 229-242.
Polat, G., Ugan, R.A., Cadirci, E. \& Halici, Z. 2017. Sepsis and septic shock: Current treatment strategies and new approaches. Eurasian Journal of Medicine 49(1): 53-58.

Suzuki, T., Suzuki, Y., Okuda, J., Kurazumi, T., Suhara, T., Ueda, T., Nagata, H. \& Morisaki, H. 2017. Sepsis-induced cardiac dysfunction and $\beta$-adrenergic blockade therapy for sepsis. Journal of Intensive Care 5(1): 22.

Wang, Z., Wu, G., Liu, H., Xing, N., Sun, Y., Zhai, Y., Yang, B., Kong, A.N., Kuang, H. \& Wang, Q. 2017a. Cardioprotective effect of the xanthones from Gentianella acuta against myocardial ischemia/reperfusion injury in isolated rat heart. Biomedicine \& Pharmacotherapy 93: 626-635.

Wang, F., Jin, Z., Shen, K., Weng, T., Chen, Z., Feng, J., Zhang, Z., Liu, J., Zhang, X. \& Chu, M. 2017b. Butyrate pretreatment attenuates heart depression in a mice model of endotoxininduced sepsis via anti-inflammation and anti-oxidation. The American Journal of Emergency Medicine 35(3): 402-409.

Zhao, P., Wang, Y., Zeng, S., Lu, J., Jiang, T.M. \& Li, Y.M. 2015. Protective effect of astragaloside IV on lipopolysaccharideinduced cardiac dysfunction via downregulation of inflammatory signaling in mice. Immunopharmacology and Immunotoxicology 37(5): 428-433.

Liu Xianchu, Li Sha, Chen Ruyan, Li Yue \& Liu Ming* Department of Human Movement Science

Institute of Physical Culture

Hunan University of Arts and Science

415000 Changde, Hunan

People's Republic of China

Liu Xianchu

Key Laboratory of Physical Fitness and

Exercise Rehabilitation of Hunan Province

Hunan Normal University

410081 Changsha

People's Republic of China

Peng Huan

Department of Hematology

Xiangya Changde Hospital

415000 Changde, Hunan

People's Republic of China

*Corresponding author; email: liuminghappy36@163.com

Received: 16 May 2019

Accepted: 15 September 2020 